\title{
A new species of Paraceratotingis Henry, Montemayor \& Knudson from Guyana (Hemiptera, Heteroptera, Tingidae)
}

\author{
Alexander H. Knudson' \\ I Department of Entomology, North Dakota State University, NDSU Dept. 7650, P.O. Box 6050, Fargo ND \\ 58108-6050, USA \\ Corresponding author: Alexander H. Knudson (alexander.knudson.2@ndsu.edu) \\ Academic editor: A. Wheeler | Received 18 December 2017 | Accepted 17 May 2018 | Published 15 November 2018 \\ http://zoobank.org/8488C130-6D75-4DB7-84CA-98EFBFA3EBAD \\ Citation: Knudson AH (2018) A new species of Paraceratotingis Henry, Montemayor \& Knudson from Guyana \\ (Hemiptera, Heteroptera, Tingidae). In: Wheeler Jr AG (Ed.) A Festschrift Recognizing Thomas J. Henry for a Lifetime \\ of Contributions to Heteropteran Systematics. ZooKeys 796: 301-305. https://doi.org/10.3897/zookeys.796.23076
}

\begin{abstract}
Paraceratotingis henryi sp. n., is described from Guyana. Color photographs and a diagnostic key are provided to aid in distinguishing the species of Paraceratotingis Henry, Montemayor, and Knudson. Diagnoses are also provided.
\end{abstract}

\section{Keywords}

Heteroptera, lace bugs, Tigava complex

\section{Introduction}

The genus Paraceratotingis Henry, Montemayor, and Knudson was erected by Henry et al. (2017) to accommodate two peculiar specimens that were thought to represent a new species of Ceratotingis Montemayor (2008). On further examination, Henry et al. (2017) determined that this new species actually belongs in a new genus of the Tigava generic complex. Subsequently, while sorting through specimens from the Natural History Museum in London, a single specimen representing another new species of Paraceratotingis was discovered, which is described herein. 


\section{Materials and methods}

The specimens examined for this paper are from the Natural History Museum (London) (NHMUK), and the United States National Museum of Natural History (USNM) in Washington, DC. Specimens were examined using a Wild M5 stereomicroscope with 10x eyepieces and an ocular doubler. Precision Digital Positioners (Model 3486-1, Boeckler Instruments, Tucson, Arizona) connected to Microcode Digital Dials (IKL Inc., Newport Beach, California) were used to take measurements, which are given in millimeters $(\mathrm{mm})$. Multiple photographs were taken using a Canon EOS 7D with an Automatic Extension Tube Set (Model DG, Kenko Tokina Co., Ltd., Tokyo, Japan) and a macro photo lens (Model MP-E 65mm, Canon, Inc. Tokyo, Japan) attached to a Stack Shot motorized rail (Cognisys, Inc., Traverse City, Michigan). Photographs were then montaged and edited in Adobe Photoshop CS 6.

\section{Results}

The discovery of a new species of Paraceratotingis necessitates a slight modification of the generic description to accommodate the new species. In the original description of the genus, it was stated that the head has three spines, a pair of occipital spines and a median spine. The new species described in this paper lacks the median spine. Additionally, Paraceratotingis was originally defined as having the paranota and the costal and subcostal areas of the hemelytra each with two rows of areoles. The new species has all of these areas with only a single row of areoles. The discoidal cell in $P$. convergens Henry, Montemayor, and Knudson (the type species) is closed apically, whereas in the new species the discoidal area is open apically.

\section{Key to the species of Paraceratotingis}

$1 \quad$ Head with pair of occipital spines and median spine; paranota, costal, and subcostal areas of hemelytra biseriate

Paraceratotingis convergens Henry, Montemayor \& Knudson

- $\quad$ Head with pair of occipital spines, median spine lacking; paranota, costal, and subcostal areas of hemelytra uniseriate Paraceratotingis henryi sp. $\mathrm{n}$.

\section{Paraceratotingis convergens Henry, Montemayor \& Knudson, 2017}

Paraceratotingis convergens Henry, Montemayor \& Knudson, 2017: 272-273, figs $7,13-14$.

Diagnosis. Head with pair of extremely long occipital spines and median spine. Paranota biseriate. Pronotal collar produced upward, forming small, elevated, distinct 
hood. Hemelytra slightly broader, costal and subcostal areas biseriate; discoidal area closed apically.

Material examined. HOLOTYPE: VENEZUELA: Aragua, El Limón, 4 July 1968, J. Maldonado C. (ðUSNM).

\section{Paraceratotingis henryi sp. $\mathrm{n}$.} http://zoobank.org/A83E8D61-D3AA-4F6F-AE67-E5155BF9230E Figs $1-3$

Holotype. GUYANA: Demerara, Soweyo GDF Camp, 27-30 Sept 1991, JH Martin Coll., BM1991-182 (†NHMUK). Red handwritten label: Holotype Paraceratotingis henryi n. sp. Knudson 2018.

Diagnosis. Head with pair of moderately long occipital spines; medial spine lacking. Paranota uniseriate. Pronotal hood moderately elevated. Hemelytra slightly narrower, costal area uniseriate; subcostal area uniseriate; discoidal area open apically.

Description. Head. Pale brown; armed with two spines, occipital spines moderately long, converging, but not meeting medially; occipital plates of head lighter in color, obscured by pale wax near bases of antennae; clypeus swollen; eyes bulging, large, $1 / 3$ of head width in dorsal view. Antennae extremely long; segment one long, lightly infuscate, brown, covered with several regular rows of setae; segment two short, concolorous with head, with regular rows of hairs; segment three long, 1.5 times longer than first antennal segment, lighter in color, with regular rows of hairs; segment four clavate, concolorous with preceding segment on basal fourth, black to apex, with longer stouter hairs. Bucculae yellowish, lighter colored than head, bi- to triseriate. Rostrum moderately elongate, apex extended to middle of prothoracic sternite; basal segment brownish, concolorous with basal antennal segment; remaining segments yellow brown except last segment infuscate apically.

Thorax. Pronotum light brown, mostly concolorous with head; tricarinate, punctate, areolate in triangular posterior projection; carinae uniseriate, low, yellowish; pronotal collar lighter in color, slightly tumid, elevated to form hood-like structure; calli large, triangular, lightly pruinose; paranota uniseriate, with minute spinules and pruinescence at outer margins, yellowish. Hemelytra elongate, surpassing abdomen by one fourth to one third its length; outer margin light yellow, with hyaline areolae; costal area of hemelytra uniseriate, with rectangular areolae; subcostal area mostly hyaline, with veins yellowish, subcostal area of wing about two thirds width of costal area, uniseriate with regular areolae; discoidal area poorly differentiated, with five to six rows of areolae at greatest width, open behind; sutural area completely overlapping, wide, with eight to nine rows of areolae at greatest width, cells infuscate, veins brownish,. Hind wings surpassing abdomen in repose, extended halfway between abdomen and hemelytra. Rostral laminae low, uniseriate; sternites dark brown to black. Legs subequal in length, coxae concolorous with pleurites, femora and tibiae elongate, tibiae each with several longitudinal rows of setae, slightly clavate apically, infuscate at apex, with pad of hairs on ventral margin; tarsi darkly infuscate. Ostiolar peritreme small, nearly obsolete. 

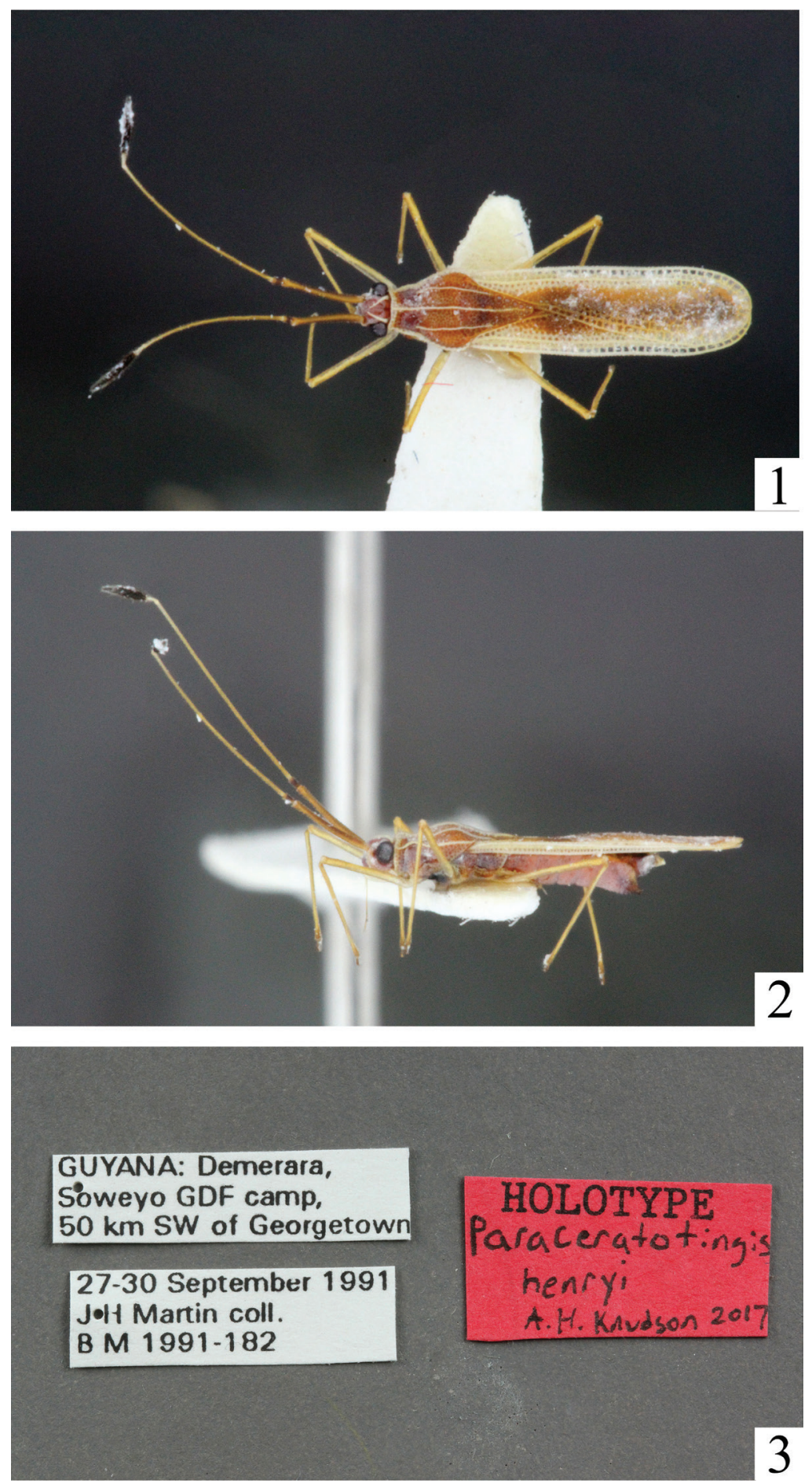

Figures I-3. I Dorsal habitus of Paraceratotingis henryi 2 Lateral habitus of Paraceratotingis henryi 3 Labels of Paraceratotingis henryi. 
Abdomen. Light brown, sternites broad; pregenital plate scalloped, with two angular projections along lateral posterior margins; gonocoxae slightly excavated at posterior ventral margin, pruinose.

Etymology. This species is named in honor of Dr. Thomas J. Henry, USDA Systematic Entomology Laboratory, National Museum of Natural History, Washington, DC, for his great contributions to the study of Heteroptera, specifically his advances to the systematics of the Miroidea and Lygaeoidea.

\section{Discussion}

Paraceratotingis henryi can be separated from $P$. convergens by the characters provided in the diagnoses. Paraceratotingis convergens is known only from Venezuela, and the new species described herein is known only from Guyana, suggesting that the genus might be endemic to northern South America. No biological information is available for species of Paraceratotingis, but a related genus, Ceratotingis, has been found feeding and breeding on Cecropia sp. (family Urticaceae) in Costa Rica (Kenji Nishida and Paul Hanson, personal communication). Paraceratotingis might also feed on members of this genus or other Urticaceae.

\section{Acknowledgments}

Sincere gratitude is expressed to Mick Webb and Max Barclay (NHMUK) for the loan of material used in this study. I also thank Sara Montemayor for her guidance and advice on the Tigava complex. I am indebted to my advisor David Rider, Eric Guilbert, and $\mathrm{Al}$ Wheeler for their timely and constructive reviews of this manuscript. Lastly, I express my appreciation to Thomas J. Henry (USNM) for his continual enthusiastic guidance and support of my developing career. Happy birthday Tom and thank you very much!

\section{References}

Henry TJ, Montemayor SI, Knudson AH (2017) Review of the New World Tigava lace bug complex (Hemiptera: Heteroptera: Tingidae), with the description of two new genera and two new species and a key to genera. Dugesiana 24(2): 269-277.

Montemayor SI (2008) A new genus and two new species of Tingidae (Heteroptera) from Central America. Zoological Science 25: 444-450. https://doi.org/10.2108/zsj.25.444 